\title{
A Revision of the Scaphopoda from Australian Waters (Mollusca)
}

\author{
KEVIN L. LAMPRELL ${ }^{1} \&$ JOHN M. HEALY ${ }^{2}$ \\ ${ }^{1}$ Malacology Section, Australian Museum, 6 College Street, Sydney New South Wales 2000, Australia; \\ postal address: 58 Marsden Road, Kallangur Queensland 4503, Australia \\ ${ }^{2}$ Department of Zoology, University of Queensland QLD 4072, Australia
}

\begin{abstract}
The extant Australian fauna of the molluscan class Scaphopoda is reviewed. In total 108 species are recognized, of which 47 are new and 28 represent named species not previously recorded from the Australian region. Both scaphopod orders-Dentaliida and Gadilida-are well represented in the extant fauna, especially the Dentaliida with 79 species (59 in Dentaliidae alone). The following families and genera were noted, with the numbers of species in each genus indicated in brackets. Order Dentaliida-Dentaliidae, Dentalium s.st. (38 including 16 new) Dentalium (Lentigodentalium) (3 including 2 new), Dentalium (Pictodentalium) (1), Tesseracme (3 including 1 new), Fissidentalium (11 including 6 new), Graptacme (3 including 1 new); Fustiariidae, Fustiaria (2); Laevidentaliidae, Laevidentalium (13 including 5 new); Omniglyptidae, Omniglypta (2); Gadilinidae, Episiphon (4 including 2 new); Order Gadilida Entalinidae, Entalina (2 including 1 new), Bathoxiphus (4 including 2 new); Pulsellidae, Pulsellum (2 including 1 new), Compressidens (1); Gadilidae, Gadila (9 including 4 new), Cadulus (5 including 3 new), Dischides (2 including 1 new), Polyschides ( 3 including 2 new). The Omniglyptidae are recorded for the first time from Australia. Some previously named "species" are removed from the fauna (Tesseracme beachportensis Cotton \& Ludbrook, probably a portion of a pennatulid rachis) or treated as unrecognizable (Dentalium weldianum Tenison-Woods, D. tasmaniensis Tenison-Woods). Full descriptions, comparisons and distribution maps are given for each valid species. In addition a series of keys are provided for the identification of Australian scaphopods from the level of order down to species. Reference is also made to the fossil scaphopods from Australia, although no attempt is made to review those species taxonomically. Laevidentalium largicrescens (Tate), formerly known only from Tertiary deposits is recorded as living in deep water from Bass Strait to southern Queensland.
\end{abstract}

Lamprell, Kevin L., \& John M. Healy, 1998. A revision of the Scaphopoda from Australian waters (Mollusca). Records of the Australian Museum, Supplement 24: 1-189. 